\title{
KONSEP DASAR PERTUNJUKAN WAYANG SINEMA LAKON DEWA RUCI
}

\author{
Sunardi \\ Fakultas Seni Pertunjukan Institut Seni Indonesia Surakarta \\ gunowijoyo@gmail.com \\ I Nyoman Murtana \\ Fakultas Seni Pertunjukan Institut Seni Indonesia Surakarta \\ Sudarsono \\ Fakultas Seni Pertunjukan Institut Seni Indonesia Surakarta
}

\begin{abstract}
This paper aims to describe the basic concepts of wayang cinema performance Dewa Ruci play as an alternative to the development of Indonesian puppets. Wayang Cinema is an innovative wayang performance in a wide-screen film. The problems examined are: (1) what lies behind the creation of wayang cinema Dewa Ruci play; and (2) what is the basic concept and structure of wayang cinema performance Dewa Ruci play. The study was conducted by applying the methods of art creation, namely exploration, design, creation, and presentation. The results showed that: first, the creation of wayang cinema Dewa Ruci play was motivated by the decreasing of younger generation's interest in wayang. The wayang life is marginalized, responding to the challenges of the era namely the industrial era 4.0., And as a continuation of puppet show experiments. Secondly, the basic concept of wayang cinema Dewa Ruci play is to emphasize the work on the play and the presence of the song as a driver of plot, characterization, and strengthening the atmosphere, in addition to being packaged in the form of widescreen films. Third, the structure of wayang cinema Dewa Ruci play emphasizes the portrayal of the Bima figure in achieving tirta pawitra with a new style.
\end{abstract}

Keywords: basic concepts, wayang cinema, Dewa Ruci's play, young generation's interest.

\section{PENDAHULUAN}

Arus globalisasi dan revoluasi industri 4.0 yang melanda dunia, termasuk Indonesia berdampak pada perubahan sosial dan budaya masyarakat. Intervensi produk teknologi modern dan massalisasi media massa memiliki pengaruh besar terhadap pembentukan kecenderungan baru di kalangan masyarakat Indonesia, terutama terkait dengan daya apresiasi seni tradisi (wayang). Berbagai alternatif seni, seperti seni populer dan seni industri kreatif, membentuk minat baru sehingga menggeser kesadaran mereka untuk mencintai dan menghargai keseniannya sendiri dalam perspektif modern.

Di sisi lain, lunturnya minat masyarakat terhadap wayang disebabkan pola transmisi seni tradisi dari generasi satu kepada generasi berikutnya mengalami kemandegan (Rustopo, 1991). Beberapa faktor mendasar yang menyebabkan masyarakat kurang apresiatif terhadap wayang, yaitu: aspek kebahasaan, muatan cerita, dan durasi pertunjukannya. Bahasa Jawa dengan struktur rumit menjadi kendala bagi masyarakat, terutama generasi muda untuk memahami dan menangkap makna cerita. Jika dicermati, muatan cerita wayang lebih berorientasi pada pola pikir orang tua karena cerita yang dibeberkan mengandung pesan yang hanya dipahami orang tua dari pada generasi muda. Pada persoalan lain, masyarakat disuguhi pertunjukan wayang berdurasi lama menyebabkan kejenuhan dan kurang responsif dengan wayang. Mereka tidak memiliki ketahanan untuk berlama-lama mengapresiasi wayang, karena faktor pekerjaan ataupun rutinitas sekolah. Kondisi eksternal dan internal inilah yang menjadi tantangan bagi upaya pengem-bangan wayang Indonesia agar diminati masyarakat berbagai kalangan dan menyesuaikan perkembangan zaman di era industri digital dewasa ini.

Wayang sinema menjadi alternatif bagi upaya pengembangan wayang Indonesia dengan memadukan unsur tradisional dan teknologi modern. Wayang sinema adalah bentuk pertunjukan wayang konvensional klasik yang dikemas dalam bentuk film atau sinema. Wayang ini mengangkat cerita wayang 
purwa dalam bingkai film layar lebar. Boneka wayang kulit dipadukan dengan komposisi musik gamelan yang dikreasi dengan pendekatan modern, yakni penggunaan teknologi komputer, sinematografi, dan pemakaian teks bahasa Indonesia sebagai pengantar cerita. Wayang sinema menjadi model pengembangan wayang Indonesia untuk masyarakat dewasa ini. Inovasi pertunjukan wayang sinema sebagai respons terhadap era industri 4.0, dengan mengeksplorasi kekuatan seni tradisi yang dikemas dengan teknologi modern untuk menghasilkan produk seni budaya yang dapat memenuhi selera pasar. Di sinilah pentingnya berkreasi wayang dengan paradigma industri kreatif. Pertunjukan wayang sinema dapat dijadikan produk industri kreatif untuk menjangkau segmen masyarakat secara luas.

Pertunjukan wayang sinema lakon Dewa Ruci memiliki urgensi bagi pengembangan seni pertunjukan wayang Indonesia dalam menghadapi era industri dewasa ini. Wayang sinema dapat dijadikan referensi bagi pemajuan kebudayaan untuk pembangunan ketahanan bangsa, terutama mewujudkan manusia Indonesia yang berkepribadian dalam kebudayaan. Wayang sinema lakon Dewa Ruci dengan muatan nilainilai budi pekerti menjadi wahana edukasi bagi masyarakat untuk membentuk moralitas bangsa. Dalam kerangka keilmuan, model pertunjukan wayang sinema mengandung dimensi metodologi penciptaan seni untuk membangun disiplin ilmu seni. Metodologi penciptaan seni memuat berbagai konsep, seperti konsep estetika, konsep etika, konsep kreativitas, dan konsep artistik. Model pertunjukan wayang sinema dapat diimplementasikan sebagai: (1) produk inovasi seni untuk menjawab tantangan zaman; (2) materi apresiasi seni pertunjukan wayang bagi masyarakat Indonesia; serta (3) media pengajaran nilai-nilai budi pekerti.

\section{KAJIAN LITERATUR}

Inovasi dan kreasi pertunjukan wayang telah dilakukan beberapa kreator bidang seni pedalangan. Trisno Santoso mencipta pertunjukan wayang golek baru dengan judul "Wayang Boneka Wong Agung Jayengrana" (2016). Substansi dari karya ini adalah menciptakan format pertunjukan wayang golek baru yang memiliki perbedaan dengan wayang golek pada umumnya. Santoso menekankan pada kebaharuan dalam proses dan penyajian, boneka wayang, tata panggung, struktur adegan, pemain, durasi penyajian, dan musik pertunjukan. Tujuan penciptaan karya ini agar wayang golek dapat lebih menarik, efisien, dan multiguna sebagai apresiasi seni dan media pembelajaran.

Model penciptaan pertunjukan wayang juga dapat diketahui dari hasil inovasi Dwi Suryanto dengan judul "Wayang Terawang Lakon Anoman Sang Maha Satya" (2007). Suryanto menekankan pentingnya inovasi tampilan wayang pada layar, sehingga mencipta variasi layar dan tata lampunya. Melalui karya ini Suryanto mengajak publik untuk melihat wayang dengan perspektif yang berbeda. Walaupun cerita bersumber dari lakon Anoman Duta (pakeliran klasik), namun telah digubah dalam nuansa berbeda, yakni pada desain panggung, layar, tata lampu, musik, dan gaya penceritaan. Wayang terawang memberikan pemahaman ketika orang melihat wayang seolah-olah melihat negatif film dengan cara menerawang.

Beberapa karya inovatif lainnya dapat dilihat pada karya Blacius Subono yang menyajikan karya berjudul "Wayang Lingga-Yoni Lakon Pengakuan Seorang Pradana" (2002). Konsep penciptaan wayang lingga-yoni mengacu pada makna kesuburan yaitu persatuan hubungan manusia dalam mencapai keselarasan hidup yang disimbolisasikan melalui hubungan antara pria dan wanita. Wayang lingga yoni dikemas dalam pertunjukan multimedium dengan menampilkan kekuatan panggung pertunjukan, efek bayangan, tata lampu, dan lakon yang disampaikan. Inovasi wayang juga telah dilakukan oleh Frank Fosdahl dengan karya berjudul "Lakon Wayang Wahyu Binuka Wahyu Jati Manunggal” (2004). Dalam hal ini, Fosdahl membeberkan cerita wayang yang bersumber dari Kitab Injil, yakni kelahiran Yesus sang juru selamat di dunia. Konsep penciptaan didasarkan pada kekuatan wayang untuk presentasi syiar agama. Karya ini menampilkan desain panggung wayang, teknik memainkan wayang, karawitan, dan lakon yang disajikan dengan mengacu pada pakeliran sandosa.

Penelitian mengenai inovasi pertunjukan wayang telah dilakukan oleh penulis dengan menghasilkan kreasi pertunjukan wayang dalam beberapa genre. Model pertunjukan wayang kulit inovatif, telah dilakukan Sunardi, Kuwato, dan Zulkarnaen Mistortoify dalam penelitian berjudul "Wayang Transparan: Wayang Eksperimen Berbahasa Indonesia sebagai Sarana Transmisi Pendidikan Budi Pekerti bagi Siswa SLTA di Surakarta" (2009). Tulisan ini mengupas tentang konsep penyusunan wayang transparan, yang meliputi konsep artistik, seperti: lakon, bahasa wayang, gerak wayang, musik wayang, tata rupa panggung, dan bentuk boneka wayang; dan konsep estetikanya, yaitu menarik, 
spektakuler, dan mengungkapkan nilai-nilai budi pekerti bagi generasi muda.

Model kreasi dan inovasi pertunjukan wayang juga termuat pada tulisan berjudul Buku Panduan Praktik Pakeliran Golek Padat (2010) susunan Jaka Rianto, Sunardi, dan Titin Masturoh. Buku ini mengupas mengenai tiga lakon wayang golek garapan baru, yaitu Timun Emas, Amir Meguru, dan Maktal Tobat. Secara substantif buku ini disusun untuk menghasilkan model panduan praktik mendalang pakeliran golek padat bagi anak-anak usia sekolah dasar. Misi utama dari buku ini terkait dengan penanaman pendidikan budi pekerti bagi siswa sekolah dasar yang dikemas dalam lakon wayang golek. Dalam buku ini dilengkapi sinopsis cerita, panduan praktik antawecana, sulukan, gending, keterangan gerak wayang, tokoh yang tampil, dan gambar-gambar adegan dalam pergelaran.

Kreasi model pertunjukan wayang, juga dilakukan penulis yaitu karya seni pertunjukan wayang gedog, wayang babad, dan wayang perjuangan. Sunardi, Bambang Suwarno, dan Bagong Pujiono dalam buku berjudul Revitalisasi dan Inovasi Wayang Gedog (2014) telah menyusun model pertunjukan wayang gedog garap ringkas sebagai upaya pelestarian dan pengembangan wayang langka. Pada prinsipnya penelitian ini dilakukan dengan proses kreasi dan inovasi pertunjukan wayang gedog yang siap dipergelarkan dalam berbagai even. Pada pengkajian tentang Wayang Babad Nusantara Media Pengajaran Nilai Kebangsaan (2016), Sunardi, Sugeng Nugroho, dan Kuwato berhasil menciptakan model pertunjukan wayang untuk media pembelajaran sejarah bangsa Indonesia bagi siswa sekolah dasar. Kreasi dan inovasi yang dilakukan dapat diperlihatkan dari bentuk boneka wayang, gending, bahasa pengantar, dan tampilan pertunjukan. Wayang babad memiliki muatan pengajaran sejarah para raja di Nusantara, diantaranya tercermin pada lakon Sumpah Palapa dan lakon Pangeran Diponegoro.

Upaya inovasi juga dilakukan Sunardi, Kuwato, dan Sudarsono dalam buku berjudul Estetika Pertunjukan Wayang Perjuangan (2017). Buku ini memaparkan tentang inovasi pertunjukan wayang perjuangan sebagai pengajaran pendidikan bela negara bagi generasi muda. Dalam paparannya dikemukakan mengenai konsep estetika, proses kreasi dan inovasi, serta bentuk pertunjukan wayang perjuangan. Pengajaran bela negara tercermin dari pertunjukan wayang perjuangan lakon Gerilya Jenderal Soedirman. Penelitian yang akan dilakukan ini berorientasi pada kreasi dan inovasi pertunjukan wayang sinema lakon
Dewa Ruci sebagai alternatif pengembangan wayang Indonesia. Atas dasar karya cipta dan literatur tersebut, dapat dinyatakan bahwa dalam proses kekaryaan seni pedalangan diperlukan adanya konsep ataupun teori penciptaan seni.

\section{METODE PENELITIAN}

Lokasi penelitian di Kota Surakarta, Kabupaten Karanganyar, Kabupaten Klaten, Kabupaten Sukoharjo, dan Daerah Istimewa Yogyakarta, dengan alasan: (1) lima wilayah ini merupakan lokus budaya wayang yang sangat kuat ditunjang infrastruktur pendukung, yaitu: Keraton Kasunanan Surakarta, Pura Mangkunegaran, Taman Budaya Jawa Tengah, dan lainnya; (2) tersedia SDM seniman dalang, budayawan, kreator wayang, sastrawan, sineas, peneliti, praktisi seni yang memiliki pengetahuan mendalam mengenai seni pertunjukan wayang Indonesia.

Sumber data berupa: (1) pustaka, yang memuat tentang wayang Indonesia. Sumber data ini diperoleh dari berbagai perpustakaan; (2) audio-visual, meliputi berbagai rekaman pertunjukan wayang Indonesia, yang digali dari Perpustakaan pandang-dengar ISI Surakarta dan sumber internet (youtube.com); dan (3) narasumber, terdiri atas para dalang, kreator wayang, sastrawan, budayawan, sineas.

Pengumpulan data dilakukan dengan studi pustaka, wawancara, observasi, rekam audio visual, dan pemotretan. Studi pustaka digunakan untuk mengidentifikasi wayang Indonesia. Wawancara mendalam didukung dengan rekam suara dilakukan terhadap narasumber utama untuk menggali genre wayang, boneka wayang, lakon wayang, kreasi wayang, inovasi wayang dan sebagainya. Teknik observasi untuk mengamati beberapa bentuk inovasi pertunjukan wayang untuk dieksplorasi menjadi bentuk baru. Rekam audio-visual dan pemotretan untuk melengkapi data hasil observasi yang tidak tertangkap peneliti.

Proses inovasi dilakukan dengan cara eksplorasi, perancangan, kreasi, dan presentasi. Pertama, eksplorasi dilakukan untuk menemukan materi utama terhadap alat dan bahan serta data-data yang telah ada. Kedua, perancangan dilakukan untuk menemukan konsep pertunjukan wayang sinema lakon Dewa Ruci yang memiliki kebaharuan. Ketiga, kreasi pertunjukan untuk menemukan format pertunjukan wayang sinema yang menarik dan berkualitas. Keempat, presentasi hasil inovasi pertunjukan wayang sinema lakon Dewa Ruci kepada masyarakat. 


\section{HASIL DAN PEMBAHASAN}

\section{A. Latar Belakang Pertunjukan Wayang Sinema}

Wayang sinema merupakan inovasi pertunjukan wayang dalam kemasan film layar lebar. Pertunjukan wayang dengan beberapa unsurnya, seperti: pelaku pertunjukan (dalang, pengrawit, pesinden, penggerong, dan kru pertunjukan); peralatan pertunjukan (wayang, kelir, kothak, cempala, keprak, gamelan, lampu, dan pengeras suara); dan unsur garap pertunjukan (lakon, sabetan, antawecana, dan iringan pakeliran) dikemas dengan menerapkan teknologi komputer dan sinematografi. Pertunjukan wayang sebagai materi utama yang diedit dan dikemas menjadi film. Oleh karena itu, perlu kehadiran materi lain (stock shoot), seperti hutan, deburan ombak, samodera, langit, hujan, matahari, binatang, dan sebagainya yang dipadukan dengan pertunjukan lakon wayang.

Jika dicermati, embrio dari pertunjukan wayang sinema sesung-guhnya sudah ada semenjak tahun 1980-an, yaitu Pakeliran Sandosa (Sunardi, 2004). Bentuk pakeliran sandosa adalah pertunjukan wayang dengan layar lebar, diiringi musik gamelan, dengan tekanan pada penggunaan bahasa Indonesia sebagai pengantar cerita. Pakeliran Sandosa pernah dipertunjukan dalam even Festival Film Indonesia di Bandung. Hal ini didasarkan pada kemiripan penggunaan layar sebagai media utama, selain fokus perhatian penonton juga tertuju pada layar. Baik film maupun Pakeliran Sandosa mendudukkan layar menjadi signifikan untuk wahana komunikasi antara seniman atau sineas dengan penontonnya.

Setelah Pakeliran Sandosa menggejala di masyarakat pedalangan, muncul berbagai kreasi dan inovasi wayang dengan berbagai bentuk, seperti pakeliran layar panjang, pakeliran tiga layar, wayang televisi (termasuk kala sinema dan cempala), dan wayang sinema. Bentuk-bentuk pakeliran atau pertunjukan wayang ini sesungguhnya memberikan alternatif tontonan wayang dalam berbagai format. Aneka ragam wayang ini diperuntukkan bagi masyarakat secara luas dengan kreasi lakon yang menarik masyarakat pada umumnya.

Pakeliran layar panjang merupakan satu bentuk pertunjukan wayang dengan menggunakan layar panjang. Pakeliran ini menampilkan tiga dalang utama yang duduk berjajar dengan posisi di sebelah kiri, posisi tengah, dan posisi sebelah kanan. Ketiga dalang bermain wayang secara bersamaan maupun bergantian sesuai dengan skenario yang telah disusun sutradara. Pergantian adegan, layar, dan dalang ditunjukkan dengan permainan lampu sebagai kodenya. Apabila ketiga lampu hidup berarti ketiga dalang bermnain bersamaan, jika hanya lampu kiri, atau tengah, atau kanan berarti hanya dalang tertentu yang memainkan wayang. Pakeliran layar panjang menggunakan bahasa Indonesia ataupun bahasa Jawa sebagai pengantar cerita. Adapun lakon yang disajikan adalah lakon wayang konvensional yang telah disanggit dengan paradigma baru yakni mengacu pada konsep dramaturgi. Pakeliran layar panjang telah ada semenjak zaman Orde Lama, dan dihidupkan kembali oleh para mahasiswa Jurusan Pedalangan angkatan 1989. Tokoh pembaharu pertunjukan pakeliran layar panjang yaitu Slamet Gundono dan kawan-kawan. Pakeliran layar panjang pentas perdana pada tahun 1993 di Taman Budaya Jawa Tengah di Surakarta dengan lakon Dewabrata" dengan dalang Ki Purwoto, Ki Nyoman Pramono, dan Ki Sunardi. Pentas perdana ini mendapat sambutan positif dari para seniman dalang di Surakarta. Pada perkembangan berikutnya, pakeliran layar panjang diikutsertakan dalam Festival Republika di Jakarta pada tahun 1994 dengan memperoleh predikat sebagai penyajian terbaik. Pakeliran layar panjang pada perkembangan berikutnya dikreasi oleh para mahasiswa Jurusan Pedalangan yang terhimpun pada Himpunan Mahasiswa Jurusan Pedalangan untuk dipentaskan pada karya kreativitas mahasiswa di akhir tahun pelajaran. Pertunjukan pakeliran layar panjang mengandung aspek sinematografi, hal ini terlihat pada penggunaan layar panjang seperti layar film; dan fokus perhatian penonton pada bayangan di atas layar. Ini artinya bahwa orang melihat pertunjukan pakeliran layar panjang layaknya menyaksikan film layar lebar.

Munculnya pakeliran layar panjang menginspirasi para dalang tradisional untuk menyajikan pertunjukan wayang dengan tiga dalang atau lebih dengan menggunakan layar panjang. Salah satu bentuk pakeliran yang menggejala pada tahun 1995an adalah pakeliran pantap. Pakeliran Pantap adalah singkatan dari pakeliran apresiasi tetap, yang digagas oleh Ir. Sudjadi dan dipergelarkan tiap tanggal 17 pada tiap bulannya di halaman kantor Gubernur Jawa Tengah (Kuwato, 2001). Pada perkembangannya pakeliran ini dipentaskan di berbagai tempat, bahkan pada masa ini telah muncul gejala penjamakan wayang. Supanggah menyatakan bahwa wayang telah dikreasi dalam bentuk yang spektakuler dan serba besar atau diistilahkan dengan fenomena penjamakan wayang. Estetika wayang telah berubah menjadi estetika yang entertainment sifatnya dengan memberikan nuansa 
ramai dan spektakuler pada setiap pertunjukan para dalang.

Perkembangan wayang sinema dapat diamati ketika pertunjukan wayang dikemas dalam format televisi. Model wayang televisi ditengarai sebagai bentuk pengembangan wayang dengan menggunakan media dan sistem yang berlaku di dunia televisi. Model ini mendudukkan wayang sebagai objek yang dikemas menjadi satuan mata acara televisi. Dengan durasi singkat, wayang televisi dilengkapi teks diharapkan mampu menarik minat generasi muda terhadap pertunjukan wayang. Beberapa stasiun televisi semenjak tahun 1990-an hingga dewasa ini telah menayangkan pertunjukan wayang di layar kaca, yaitu Indosiar, TVRI, TATV, dan sebagainya. Program tayangan pertunjukan wayang di televisi pada umumnya hanya mengalihkan layar nyata ke dalam layar kaca, yang artinya belum dilakukan editing untuk kebutuhan acara atau format televisi. Bahasa visual yang ditampilkan belum memenuhi kualitas sebagai wayang dalam format televisi, karena pada umumnya produser hanya menampilkan wayang apa adanya dengan fokus visual yang kadang-kadang kurang relevan dengan aspek auditifnya, seperti ketika pembicaraan tokoh penting, tidak muncul tokoh yang berbicara tetapi yang muncul visual wajah pesindennya. Kelemahan lain terletak pada pemotongan adegan atau segmen untuk selingan iklan dilakukan semena-mena dan kurang memahami keutuhan adegan dalam lakon wayang.

Salah satu acara pertunjukan wayang dalam format televisi yang telah dilakukan dengan editing yang baik yaitu Kala Sinema produksi oleh Gelar dan Senawangi Jakarta pada tahun 2000. Produksi Kala Sinema telah menghasilkan beberapa lakon wayang yang layak untuk konsumsi siaran televisi. Lakon yang disajikan seperti Dewa Ruci, sangat menarik untuk ditonton karena dikemas dengan mempertimbangkan format televisi. Kala Sinema menayangkan pertunjukan wayang padat atau ringkas dari beberapa dalang populer seperti Ki Manteb Soedharsono, Ki Purbo Asmoro, Ki Sudjiwo Tedjo dan lain-lain. Sebagai produk untuk tayangan televisi, pertunjukan wayang Kala Sinema dilengkapi dengan credit title dan running text berbahasa Indonesia untuk mempermudah komunikasi dengan masyarakat Indonesia pada umumnya.

Selain Kala Sinema, terdapat program acara di TVRI Jakarta yaitu "Cempala" juga menyajikan pertunjukan wayang durasi pendek untuk apresiasi masyarakat dengan membawakan lakon yang terkait dengan propaganda program pemerintah, seperti kesehatan masyarakat, pemilu, pertanian dan sebagainya. Program Cempala ini menyuguhkan pertunjukan wayang dengan tema tertentu, selanjutnya dilakukan dialog interaktif antara penonton dengan para kreator secara live. Beberapa lakon yang disajikan diantaranya lakon Tirta Rasa Kundha untuk menggambarkan program kesehatan masyarakat, lakon Dewi Sri dan Pandawa Tani untuk merepresentasikan tema ketahanan pangan dan pertanian, dan sebagainya. Pertunjukan wayang Cempala ini telah dikemas dengan format wayang televisi, melalui pra produksi, produksi, dan pasca produksi. Editing dari beberapa stock shoot dipadukan menjadi kemasan wayang televisi dengan durasi pendek, sekitar tujuh menit.

Beberapa kreasi dan inovasi pertunjukan wayang tersebut memberi-kan stimulan bagi penulis untuk melakukan inovasi pertunjukan wayang dalam bentuk wayang sinema. Wayang sinema merupakan perpaduan antara pertunjukan wayang dengan sinema atau film. Intinya wayang sinema adalah kreasi lakon wayang klasik yang dikemas dalam format sinema, atau dapat dikatakan sebagai film wayang. Pertunjukan wayang dialihwahanakan menjadi pertunjukan film dengan mengambil lakon wayang purwa yaitu Dewa Ruci. Ini artinya wayang sinema dapat dikatakan sebagai bentuk pertunjukan wayang dengan media film layar lebar.

\section{B. Konsep Dasar Pertunjukan Wayang Sinema 1. Konsep Pertunjukan Konsep pertunjukan wayang sinema} merupakan perpaduan wayang klasik dengan disiplin sinematografi. Wayang klasik yakni wayang kulit purwa Jawa dijadikan sebagai materi atau bahan yang dikemas dengan cara pembuatan film atau sinematografi. Pertunjukan wayang dengan lakon tertentu dimainkan dalang, diiringi pengrawit dan pesinden, serta penggerong. Konsep dasar pertunjukan adalah perpaduan bentuk pertunjukan wayang purwa Jawa yang dialihkan dalam wahana film layar lebar. Aspek gerak dan bayangan wayang menjadi signifikan untuk mencirikan wayang sinema ini, selain kehadiran iringan atau musik pakeliran dan running text sebagai penguat pertunjukan wayang sinema.

Pertunjukan wayang sinema tidak dapat dipisahkan dari peran seniman (dalang, pengrawit, penggerong, pesinden), sutradara, editor, dan kameraman. Masing-masing memiliki kontribusi dalam kreasi dan inovasi wayang sinema. Dalang memiliki peran sebagai peraga wayang pada keseluruhan alur lakon. la bertanggungjawab untuk menghidupkan dan 
memberikan daya hidup pada tiap tokoh wayang yang digerakkannya. Pengrawit berperan sebagai orang yang memainkan intrumen gamelan, adapun penggerong dan pesinden bertugas melantunkan vokal, baik gerongan, tembang, sulukan, maupun sindhenan. Hasil instrumentasi gamelan dan vokal adalah rasa musikal untuk mendukung suasana adegan ataupun peristiwa dalam alur lakon pada pertunjukan wayang sinema. Dalang, pengrawit, penggerong, dan pesinden menjadi pelaku utama pada proses kreasi dan inovasi pertunjukan wayang sinema. Untuk mengemas pertunjukan wayang kulit menjadi film layar lebar dibutuhkan peran sutradara, kameraman, dan editor. Sutradara memimpin jalannya produksi film, yakni ketika pertunjukan wayang dari dalang dishooting oleh kameraman. Sutradara memberikan arahan kepada kameraman, dalang, dan pelaku pertunjukan lainnya sesuai dengan skenario yang telah ditentukan. Kamera-man bertugas mengambil gambar ketika pertunjukan wayang berlangsung maupun pada beberapa objek untuk mendukung produksi film layar lebar. Pemahaman kameraman terhadap lakon wayang sangat signifikan untuk menghasilkan visual-auditif yang berkualitas. Pada tahapan produksi film diperlukan kehadiran editor. la menjadi penentu kualitas film yang dibuat. Editor dalam pertunjukan wayang sinema setidaknya memiliki kemampuan sebagai editor yang baik dan memahami lakon wayang kulit purwa, sehingga hasil editingnya akan memiliki kualitas tinggi.

Pertunjukan wayang sinema membutuhkan dukungan alat dan bahan, baik untuk pertunjukan wayang kulit maupun untuk pembuatan film. Peralatan pertunjukan wayang menggunakan boneka wayang kulit purwa, kelir, blencong, gamelan, kothak, cempala, keprak, gedebog, gamelan, dan pengeras suara. Adapun peralatan pada pembuatan film menggunakan kamera, handycam, komputer editing, dan lampu. Peralatan pertunjukan wayang kulit dipergunakan ketika mempergelarkan lakon wayang, adapun peralatan handycam, kamera, dan komputer untuk editing film.

Seniman dalam melakukan kreasi dan inovasi pertunjukan wayang sinema dihadapkan pada segmen masyarakat atau penonton wayang. Tanggapan penonton terhadap kualitas pertunjukan wayang sinema menjadi masukan penting bagi senimannya. Oleh karena itu, kreator perlu mempertimbangkan beberapa hal, yaitu: pertama, segmen penonton dijadikan dasar untuk mengkreasi pertunjukan wayang; kedua, dinamika perubahan zaman sebagai tolok ukur mengenai trend seni. Pertunjukan wayang sinema dipersiapkan untuk menumbuhkan minat generasi muda terhadap wayang, sehingga segmen penonton anak muda menjadi orientasi garapannya. Selain itu, era revolusi industri 4.0 perlu disikapi dengan mengkreasi pertunjukan wayang sinema yang dapat dinikmati secara massal, baik melalui pemutaran film di gedung bioskop atau tempat yang representatif maupun melalui media internet.

Atas dasar pembahasan ini dapat ditekankan bahwa konsep dasar pertunjukan wayang sinema terletak pada: (a) perpaduan antara pertunjukan wayang kulit purwa dengan disiplin sinema-tografi; (b) terdapat konsep alihwahana dari pertunjukan wayang kulit menjadi pertunjukan film layar lebar; (c) memerlukan kompetensi kreator dan inovator yang memahami lakon wayang kulit maupun teknologi sinematografi; (d) membutuhkan peralatan yang memadahi, yaitu peralatan pertunjukan wayang dan peralatan pembuatan film layar lebar; dan (e) kemasan pertunjukan wayang sinema memperhitungkan segmentasi penonton sesuai dinamika perubahan zaman.

\section{Konsep Lakon Wayang Sinema}

Pemahaman lakon dalam seni pedalangan adalah cerita yang ditampilkan di atas kelir oleh dalang. Jika dicermati, pengertian lakon wayang dapat dirunut dari pertanyaan tentang lakone sapa (siapa peran utama dalam cerita), lakone apa (apa permasalahan dalam cerita), dan lakone piye (ceritanya seperti apa) (Kuwato, 1990). Baik tokoh utama, permasalahan, maupun peristiwa selalu menjadi orientasi dari lakon, sehingga persoalan tentang penokohan, konflik, dan alur cerita menjadi satu kesatuan dalam membentuk cerita wayang. Dalam disiplin dramaturgi, ketika orang menyoal mengenai lakon akan menemukan formula dramatik, yaitu alur, penokohan, setting, dan tema-amanat.

Pada pertunjukan wayang sinema, lakon yang dipilih yaitu Dewa Ruci. Cerita atau lakon ini tergolong lakon wayang klasik yang selanjutnya dikombinasikan dengan beberapa sanggit dari para dalang, acuan literatur, maupun pengembangan gagasan dan ide pencipta wayang sinema. Lakon Dewa Ruci pada umumnya dimulai dari peristiwa ketika Bima berguru kepada Durna hingga berakhir pada kembalinya Bima dari samodera menuju negara Astina. Intisari lakon adalah perjalanan Bima ketika mencari air kehidupan, dengan berguru kepada Pendeta Durna, sehingga dapat berjumpa dengan Dewa Ruci dan men-dapatkan pencerahan mengenai air kehidupan. Dalam literatur seperti Serat Dewa Ruci karangan Yasadipura maupun 
Tanaya, mengisahkan perjalanan Bima, sejak berguru kepada Durna hingga berjumpa dengan Dewa Ruci dan kembali ke Astina. Ini berbeda dengan literatur lain seperti Nawa Ruci karangan Prijohoetomo, bahwa setelah Bima berhasil menemui Dewa Ruci serta mendapatkan air kehidupan, ia tidak kembali ke Astina atau Amarta namun mendirikan Padepokan di Sumur Jalatunda bergelar Begawan Bima Suci.

Berbeda halnya dengan konsep lakon dari tradisi pedalangan yang dilakukan para dalang. Walaupun pada umumnya memiliki garis cerita yang sama yakni perjalanan Bima mencari air kehidupan, namun ada beberapa pembeda. Ganda Maktal, misalnya menampilkan adegan kadang bayu yang menghadang perjalanan Bima. Dalam sangit dan garap Ganda Maktal, Bima mendapatkan rintangan sekaligus bantuan dari kadang bayu (Anoman, Gajah Setubanda, Jajakwreka, dan Maenaka), yang memberikan variasi alur lakon Dewa Ruci. Berbeda pula dengan garapan dari Nartosabdo yang menyuguhkan adegan tepi samodera ketika Bima mengalami keraguan, tiba-tiba dikuatkan oleh tekad dua orang suami istri yang menyeberangi lautan untuk menuju pasar. Pada garap alinnya, seperti yang diungkapkan Suyati dari Wonogiri, bahwa keberanian Bima memasuki samodera dan tidak tenggelam karena memiliki ajian druhendra pemberian dewa Indra.

Konsep lakon wayang mengacu pada struktur dramatiknya, yaitu alur, penokohan, setting, serta tema dan amanat (Satoto, 1989). Dalam hal ini, hubungan atau relasi antara alur, penokohan, setting, serta tema dan amanat mampu membentuk struktur dramatik yang sesungguhnya. Kehadiran alur lakon didalamnya memuat penokohan, setting dan tema-amanat. Alur merpakan urutan peristiwa yang terjadi dalam lakon, sehingga terdapat alur yang sifatnya linear ataupun memiliki relasi kausalitas. Alur linear menggambarkan peristiwa yang satu merupakan kelanjutan peristiwa sebelumnya yang terjadi secara berurutan atau linear. Adapun alur kausalitas dimaknai bahwa peristiwa yang satu menjadi penyebab peristiwa berikutnya, baik secara berurutan maupun tidak berurutan. Konsep alur lakon pada pertunjukan wayang sinema adalah: (1) terdapat tingkatan alur, mulai dari tahap pengenalan, klimaks, hingga penyelesaian yang tercermin pada adegan-adegan tertentu; (2) dominan pada penggunaan alur kausalitas, dimana satu peristiwa menjadi penyebab dari peristiwa yang lainnya; dan (3) bangunan alur ketat, karena peristiwa berjalan secara simultan dengan peristiwa yang saling terhubung namun dalam satu kesatuan, atau dikatakan sebagai alur yang kompleks dan utuh.
Konsep penokohan ditunjukkan pada tokoh dan karakterisasi dalam pertunjukan wayang. Tokoh yang dihadirkan adalah tokoh utama (protagonis, yaitu Bima, Durna, dan Dewa Ruci), tokoh lawan (antagonis, seperti Rukmuka, Rukmakala, kadang bayu, dan Nemburnawa), serta tokoh tritagonis, seperti, Duryudana, Puntadewa, Kresna, Kunti dan sebagainya). Pada lakon Dewa Ruci, dominasi tokoh Bima terlihat pada kehadirannya dalam keseluruhan alur lakon, mulai dari prolog hingga akhir cerita. Bima mendapatkan porsi terbesar sebagai tokoh yang menggerakkan alur dan konflik lakon Dewa Ruci. Karakterisasi Bima sebagai manusia perkasa yang memiliki kemauan keras untuk mewujudkan citacitanya. Karakterisasi ini dipahami dari aspek sosiologis (hubungannnya dengan tokoh lain), aspek fisiologis (bentuk tubuh dan kegiatan fisik), serta aspek psikologis (hubungannya dengan suasana hati). Jika dicermati, konsep penokohan pada wayang sinema terindikasi dari: (1) dominasi tokoh Bima pada setiap alur, peristiwa, dan konflik cerita; (2) terdapat tiga tokoh inti yang menggerakkan keutuhan cerita yaitu, Bima, Durna, dan Dewa Ruci; (3) munculnya tokoh lawan yang dirancang sebagai penghalang perjalanan Bima, seperti kadang bayu, Rukmuka, Rukmakala, Nemburnawa; dan (4) ada keterkaitan antara satu tokoh dengan tokoh lainnya.

Konsep setting pada wayang sinema lakon Dewa Ruci jika diperhatikan sesungguhnya memiliki latar belakang, background atau setting sangat variatif, baik setting ruang dan waktu. Pada setting tempat ditemukan beberapa alam, yaitu alam kandung, alam marcapada (dunia), dan alam bawah sadar (maya). Ketika bagi, Bima berada di dalam plasenta atau alam kandung; setelah dewasa berada pada alam dunia manusia; dan ketika berjumpa Dewa Ruci, berada di alam maya. Dalam satu kesatuan lakon, terdapat beberapa setting, di antaranya, plasenta, Wana Minangsraya, Negara Astina, Gunung Reksamuka, Negara Amarta, tengah marga, tepi samodera, dalam laut, dasar laut, dan alam maya. Adapun setting waktu mengacu pada perputaran hari, yaitu waktu pagi, siang, sore, dan malam hari. Konsep setting pada wayang sinema diindikasikan dari: (1) variasi tempat yang dipilih kaitannya dengan peristiwa yang dialami Bima; dan (2) mengambil waktu sepanjang hari, mengikuti peredaran waktu.

Apabila dikaji secara mendalam, lakon Dewa Ruci dalam pertunjukan wayang sinema ini memiliki konsep lakon yang sangat kompleks, yaitu: (1) merupakan perpaduan antara berbagai sanggit lakon, baik dari literatur, tradisi pedalangan dari para dalang, 
maupun inovasi dari tim peneliti; (2) memusatkan perhatian pada garap tokoh Bima dalam keseluruhan lakon, sehingga Bima selalu dihadirkan pada setiap adegan; (3) menggunakan alur ketat dengan penekanan pada hubungan linear dan kausalitas antara adegan satu dengan adegan lainnya; (4) seting yang dihadirkan seperti halnya pada garapan lakon tradisional, yaitu Negara Astina, Gunung Reksamuka, Negara Amarta, dan Samodra Minangkalbu; dan (5) tema-amanat yang disampaikan terkait dengan usaha manusia untuk mencapai manunggaling kawula gusti.

\section{Konsep Sabetan Wayang Sinema}

Sabetan dimaknai sebagai ekspresi gerak boneka wayang secara visual yang dilakukan dalang dalam pertunjukan wayang (Sunardi, 2013). Sabetan memiliki cakupan materi yaitu: cepengan, tancepan, bedholan, solah, serta penampilan dan entas-entasan. Materi inilah yang membentuk satu kesatuan sabetan wayang. Sabetan dibentuk dari kemampuan dalang dalam menghidupkan boneka wayang melalui gerakgerik, pola lantai/blocking, dan kreasi bayangan wayang.

Material sabetan adalah boneka wayang yang dibuat dari kulit kerbau dengan pola tertentu, dipahat dan disungging serta diberi tangkai. Konsep boneka wayang menggunakan tokoh wayang klasik dengan beberapa pengembangan. Boneka wayang memiliki bentuk dan pola wayang purwa gaya Surakarta. Boneka wayang menjadi pusat perhatian penonton untuk memahami perjalanan alur ceritanya. Boneka wayang dipilih wayang berkualitas tinggi dan memiliki aspek kebaharuan bentuk.

Boneka wayang dapat menjadi hidup dan bermakna di dalam pertunjukan apabila dalang mampu menguasai teknik sabetan, seperti mampu memegang wayang dengan benar, mampu menyusun tancepan wayang dengan baik, memahami urutan pencabutan tokoh wayang, mampu menggerakkan boneka wayang, dan mampu membuat bayangan wayang secara hidup dan menjiwai. Pada intinya dalang menguasai cepengan, tancepan, bedholan, solah, serta penampilan dan entas-entasan wayang.

Cepengan merupakan teknik dalang dalam memegang boneka wayang. Konsep cepengan berorientasi pada kekuatan dalang dalam memegang wayang secara lulut, yaitu menyatunya tangan dalang dengan gapit (tangkai) wayang sehingga terkesan hidup, berjiwa, dan enak dilihat (Murtiyoso, 2007). Cepengan lulut memberikan petunjuk bahwa dalang benar-benar mampu menguasai dan menghidupkan boneka wayang hanya dengan memegang boneka wayang. Cepengan menjadi kunci pertama akan kemampuan dalang untuk menghidup-kan boneka wayang di dalam pertunjukan wayang.

Para dalang seringkali menyatakan bahwa cepengan yang baik adalah cepengan cek dadi, artinya ketika dalang memegang wayang langsung dapat digunakan atau digerakkan di kelir. Cek dadi memberikan petunjuk akan kemampuan dan refleks dalang ketika memegang wayang tanpa harus menata terlebih dahulu. Di sini boneka wayang dalam kondisi apapun dapat dipegang dalang dengan cekatan dan baik. Ekspresi cepengan dari dalang berorientasi pada tekanan, atau dapat dikatakan bahwa kuat lemahnya tangan dalang memegang cempurit wayang menjadi daya hidup dari boneka wayang. Tekanan pada cepengan dipengaruhi oleh gaya berat boneka wayang dan besar kecilnya cempurit (Sunardi, 2013). Tokoh wayang seperti bayen, putren, memerlukan tekanan lemah karena ukuran wayang kecil dan gapit yang kecil pula, sebaliknya tokoh ukuran besar seperti Rukmuka, Werkudara, Bayu, Duryudana dan lain-lain membutuhkan tekanan kuat.

Dalam pertunjukan wayang dikenal adanya tancepan, yaitu pola pencacakan wayang pada gedebog yang menggambarkan adegan atau peristiwa tertentu. Konsep dasar tancepan wayang adalah wijang, yaitu pencacakan boneka wayang pada gedebog dapat terlihat indah karena kejelasan maksud adegan atau peristiwa yang digambarkan. Tancepan memberikan petunjuk mengenai gambaran posisi boneka wayang, variasi atau pola adegan, serta status dan peranan tokoh wayang dalam lakon. Dalam pertunjukan tari, tancepan dikenal dengan istilah pola lantai, atau blocking pada pertunjukan teater. Dalam tancepan wayang memperhatikan jarak, kerapatan, dan posisi tiap-tiap boneka wayang dalam membentuk pola adegan tertentu.

Ada beberapa hal yang perlu diperhatikan dalam penyusunan tancepan wayang, seperti: ukuran wayang (besar-kecil); status tokoh wayang (raja, brahmana, ksatria, senapati, abdi, dll); peristiwa (peristiwa adegan, suasana hati tokoh); keseimbangan (tancepan kiri-kanan); posisi tokoh (gedebog bawahgedebog atas); dan bayangan wayang. Dengan mengacu pada hal-hal tersebut, dalang dapat menyusun tancepan wayang dengan berkualitas dan estetik. Tancepan wayang mereferen terhadap etika Jawa, yaitu konsep udanegara, yang di dalamnya termuat konsep rukun, hormat, dan harmoni. Udanegara atau kemungguhan dalam tancepan wayang memberikan petunjuk bahwa ada hubungan 
signifikan antara budaya Jawa dengan seni pertunjukan wayang.

Sabetan dalam pertunjukan wayang juga ditentukan oleh bedholan yang dilakukan dalang. Bedholan yang berarti cara mencabut wayang dari gedebog serta urutan tokoh yang dicabut. Konsep estetika bedholan wayang mengacu tokoh dan peristiwa pada suatu adegan di dalam lakon. Pada adegan kerajaan, urutan bedholan yaitu: raja, dayangdayang, pendeta, patih, dan punggawa lainnya; yang berbeda dengan adegan paseban jawi dengan urutan: tumenggung, senapati, patih, dan raja atau pimpinan lainnya. Ada kalanya bedholan untuk adegan tertentu dengan tokoh yang setara derajatnya atau perannya dalam lakon dilakukan secara bersamaan.

Unsur sabetan lainnya dinamakan solah, yaitu gerak-gerik tokoh wayang pada kelir. Pada estetika solah wayang mempertimbangkan konsep urip, yaitu gerakan wayang seolah-olah hidup sesuai peristiwa adegan, suasana hati tokoh wayang, ataupun karakteristik tokoh wayang (Sunardi, 2013). Untuk mencapai ekspresi solah yang berkualitas diperlukan pemahaman karakter boneka wayang, vokabuler gerak wayang, dan teknik menggerakkan wayang. Dalam satu kotak wayang, atau setidaknya dalam satu lakon memiliki beragam karakter tokohnya. Pemahaman terhadap karakter tokoh membantu dalang dalam mengekspresikan pola gerak tokoh yang dimainkan. Pola gerak didasarkan dari rangkaian vokabuler gerak wayang, maka dalang seyogyanya menguasai berbagai ragam gerak. Untuk menghasilkan gerak wayang yang berkualitas atau urip diperlukan penguasaan teknik dari dalang. Teknik menggerakkan wayang menjadi bagian penting untuk menghasilkan solah wayang sesuai karakter, peristiwa, dan suasana hati tokoh wayang.

Ekspresi solah wayang memperhitungkan tekanan, tempo, komposisi, dan sambung rapet gerak (Sunardi, 2013). Tekanan pada solah adalah kuat dan lamahnya gerak wayang untuk menggambarkan tindakan atau peristiwa tertentu. Tempo solah wayang mengacu pada cepat lambatnya gerakan tokoh wayang. Komposisi solah adalah susunan gerak atau pola gerak yang membentuk satu kesatuan makna. Adapun sambung rapet terkait dengan kecepatan dan ketepatan pergantian antara gerak satu dengan gerak lainnya. Dalam satu komposisi gerak terdapat sambung rapet antara vokabuler gerak satu dengan yang lain.

Satu lagi unsur sabetan yang tak kalah penting kehadirannya dengan unsur yang lain, yaitu penampilan dan entas-entasan. Penampilan merupakan kemunculan tokoh wayang pada kelir, sedangkan entas-entasan adalah gerak boneka wayang meninggalkan kelir, atau dalam istilah lain, wayang muncul dan wayang exit. Penampilan lebih menggambarkan hadirnya tokoh pada kelir, adapun entas-entasan menggambarkan keluarnya tokoh wayang dari kelir. Masuk-keluarnya tokoh wayang memiliki makna mendalam dalam estetika sabet wayang. Estetika penampilan mengacu pada kesan hidup atau berjiwa pada tokoh ketika tampil di kelir, atau dikenal konsep greg dalam dunia pedalangan. Greg mengandung maksud tekanan gerak pada saat wayang tampil dan berhenti. Adapun estetika entasentasan mengacu pada konsep resik, yakni bersih atau lancarnya gerakan wayang ketika meninggalkan kelir (Sunardi, 2013).

Menurut Bambang Suwarno, pengekspresian penampilan dan entas-entasan ini dapat diukur berdasarkan tekanan dan tempo. Tekanan berarti kuat dan lemahnya penampilan dan entas-entasan tokoh wayang. Pada waktu tokoh wayang tampil di kelir dan saat meninggalkan kelir memiliki tekanan yang berbeda-beda (wawancara, 2019). Tentang cepat dan lambat penampilan dan entas-entasan mengacu pada tempo yang digunakan. Tempo penampilan dan entasentasan didasarkan pada karakter, suasana hati, dan peristiwa lakon.

\section{Konsep Narasi Wayang Sinema}

Pada umumnya, pertunjukan wayang memiliki unsur garap yang disebut sebagai catur dan antawecana. Catur diartikan sebagai pengungkapan bahasa yang digunakan dalam pertunjukan wayang, terdiri dari dialog, monolog, dan narasi atau dalam istilah pedalangan disebut ginem, ngudarasa, janturan, dan pocapan. Adapun antawecana adalah ekspresi verbal pada janturan, pocapan, dan ginem dalam pertunjukan wayang (Sunardi, 2013). Jika catur menekankan pada aspek kebahasaan dalam pertunjukan wayang, sedangkan antawecana menekankan pada teknis pengekspresian catur yang dilakukan oleh dalang.

Catur dan antawecana tidak dipergunakan dalam pertunjukan wayang sinema. Hal ini disebabkan bahwa wayang sinema digarap dengan orientasi pada aspek visual dan auditif yakni sabetan wayang dan musik wayang. Aspek verbal yaitu bahasa tidak diwujudkan dalam janturan, pocapan, dan ginem, namun diwujudkan dalam teks bahasa Indonesia dan bahasa Inggris. Teks bahasa ini merupakan terjemahan dari syair dalam tembang, gerongan, dan sulukan yang dibawakan oleh sinden dan wiraswara. 
Kehadiran teks bahasa Indonesia dan bahasa Inggris ini disebut sebagai perwujudan narasi dalam pertunjukan wayang sinema. Teks-teks ini mengungkapkan alur cerita Dewa Ruci dari babak awal hingga akhir cerita. Teks-teks ini merupakan alihbahasa dari syair atau cakepan tembang, gerongan, dan sulukan. Teks-teks yang ditampilkan berupa runing text yang ada pada layar film. Teks atau yang dianggap sebagai narasi ini menggantikan peran antawecana dari dalang, sehingga dalang hanya bertugas memainkan sabetan wayang sedangkan dialog dan narasi digantikan dengan runing text.

Konsep narasi menyelipkan teks bahasa Indonesia sebagai penguat komunikasi kepada publik. Lakon disampaikan dengan tembang, gerongan, dan sulukan yang diterjemahkan ke dalam bahasa Indonesia melalui penyusunan credit title atau runing text pada pertunjukan wayang sinema lakon Dewa Ruci. Narasi berupa runing text dihadirkan pada setiap adegan yang merupakan terjemahan dari syair tembang, gerongan, dan sulukan. Pola terjemahan mengacu pada interpretasi secara bebas, artinya terjemahan yang didasarkan pada tafsir terhadap substansi syair gerongan, tembang, dan sulukan. Oleh karena bahasa tembang, gerongan, dan sulukan memiliki aturan khusus maka teknik terjemahan dilakukan dengan cara memahami pola dan bentuknya serta memahami isi atau kontennya. Pemahaman dan interpretasi sangat menentukan kualitas dari terjemahan dan perwujudannya dalam runing text. Ini artinya konsep narasi pada pertunjukan wayang sinema diwujudkan melalui kekuatan interpretasi terhadap syair tembang, gerongan, dan sulukan.

\section{Konsep Musik Wayang Sinema}

Pada pertunjukan wayang sinema, musik memiliki peranan vital dalam membangun suasana, memperkuat gambaran peristiwa, dan menjadi petunjuk alur cerita. Musik mengacu pada pembagian wilayah nada atau dikenal pathet dalam tradisi karawitan maupun pedalangan Jawa, sehingga ada pathet nem, pathet sanga, dan pathet manyura. Suasana yang terjadi dalam lakon wayang dibangun kekuatan musikal dari gending, sulukan, tembang, maupun gerongan. Aneka ragam suasana, seperti sedih, gembira, agung, jenaka, dan sebagainya termuat dalam rasa musikal dari musik wayang sinema ini. Musik juga menjadi penguat gambaran peristiwa dalam lakon wayang. Adegan kerajaan, adegan peperangan, adegan di dalam lautan dan sebagainya didukung dengan musik baik secara instumental maupun vokal. Jalinan musik yang satu dengan lainnya dari prolog hingga tancep kayon memberikan petunjuk gambaran alur lakon. Pada intinya dalam pertunjukan wayang sinema, musik berfungsi menjadi pengantar cerita menggantikan kedudukan teks bahasa (dialog dan narasi). Hal ini tercermin dalam syair-syair yang terdapat pada tembang, gerongan, sindenan, dan sulukan.

Musik yang dipergunakan adalah gamelan Jawa yang di dalamnya terdapat pola-pola gending, sulukan, gerongan, dan tembang, mengantarkan alur lakon melalui suara yang dilantunkan para penggerong, pesinden, dalang, suara gamelan, dan suara dhodhogan-keprakan. Musik menjadi kunci pergerakan alur lakon dari awal hingga akhir lakon. Inilah sebabnya ekspresi musikal dari pengrawit, pesinden, penggerong, dan dalang menjadi signifikan untuk memperkuat alur lakon pada pertunjukan wayang sinema.

Secara sederhana, gending dimaknai sebagai instrumentalia, yakni lagu yang diungkapkan melalui nada-nada. Pada pertunjukan wayang sinema menggunakan gending Jawa yang di dalamnya terdapat beragam instrumen, seperti kendang, rebab, gender, gong, kenong, bonang, siter, gambang, saron dan sebagainya. Gending ini dimainkan oleh pengrawit dengan diperkuat penggerong dan pesinden di bawah komando dalang melalui dhodhogan-keprakan. Berbagai pola gending yang digunakan, yaitu: pola ladrang, ketawang, ketawang gending, lancaran, ayakayak, srepeg, sampak, palaran dan lainnya. Pemilihan pola gending menyesuaikan dengan adegan atau peristiwa dan suasana yang dipergelarkan dalam pertunjukan wayang sinema.

Selain gending, terdapat tembang yang dipergunakan untuk memperkuat dan mempertegas alur lakon wayang sinema. Di dalam tembang terdapat syair yang menggambarkan adegan atau peristiwa yang terjadi dikombinasikan dengan sabetan wayang. Tembang dapat dilantunkan oleh dalang, pesinden, ataupun penggerong secara mandiri atau bersamaan (koor). Jenis tembang pada pertunjukan wayang sinema yaitu sekar macapat (dhandhanggula, sinom, pangkur, asmarandana, gambuh, kinanthi, durma, megatruh) maupun sekar ageng (sardula wikridhita).

Pertunjukan wayang sinema juga menggunakan sulukan sebagai penguat suasana maupun gambaran peristiwa yang terjadi. Sulukan dilantunkan oleh dalang, pesinden, ataupun penggerong, baik secara mandiri maupun koor. Beberapa jenis sulukan yang terdapat dalam pertunjukan wayang sinema, yaitu pathetan, ada-ada, dan sendhon. Pathetan memperkuat adegan dengan 
suasana agung, bebas, santai, dan sejenisnya; adaada lebih berorientasi untuk menguatkan adegan dengan suasana greget, marah, licah, dan sejenisnya; adapun sendhon lebih signifikan untuk mendukung adegan dengan suasana sedih, bimbang, dan sejenisnya. Sulukan dilantunkan mengikuti tata aturan pathet, sehingga ada sulukan pathet nem, sulukan pathet sanga, dan sulukan pathet manyura.

Hal yang tak kalah penting untuk membangun dan memperkuat peristiwa, penokohan, dan suasana adegan adalah dhodhogan-keprakan dari dalang. Dhodhogan-keprakan menjadi penanda dan penguat adegan pada keseluruhan alur lakon. Dhodhogankeprakan menuntun pada musik untuk memulai, memperlirih, mempercepat, ataupun menghentikannya. Dhodhogan-keparakan adalah bunyi cempala dan keprak yang dilakukan dalang untuk menuntun jalannya musik wayang sinema.

Pada praktiknya, penggunaan tembang, sulukan, gerongan, dan sindenan yang difungsikan untuk mengantarkan alur lakon memiliki persamaan dengan langendriyan (drama tari dengan mengandalkan tembang sebagai pengganti dialog) ataupun opera pada pertunjukan teater. Konsep langendriyan untuk mengekspresikan musik wayang sinema menjadi hal yang urgen yang mencirikan model pertunjukan wayang sinema.

\section{Struktur Pertunjukan Wayang Sinema Lakon Dewa Ruci}

Lakon Dewa Ruci memuat perjalanan hidup tokoh Bima dalam usaha mencari tirta pawitra, yang ditandai kemanunggalannya dengan Dewa Ruci. Dalam pedalangan Jawa dikenal beraneka ragam versi maupun garapan lakon Dewa Ruci. Sumber utama Serat Dewa Ruci menjabarkan perjalanan tauhid Bima meraih predikat sebagai insan khamil. Lakon Dewa Ruci memuat laku mistik dari tokoh Bima dalam mencapai kemanunggalan dengan Tuhan. Bima sebagai tokoh sentral selalu hadir dalam keseluruhan alur lakon. Pada tahap awal, Bima berniat berguru kepada Druna untuk mendapatkan petunjuk cara menemukan air kehidupan. Tahapan berikutnya, Bima melakukan perjalanan panjang untuk mendapatkan cita citanya. Mula-mula Bima pergi ke hutan untuk mendapatkan tirta pawitra, selanjutnya ia memasuki samodera. Perjalanan Bima mendapatkan rintangan dari keluarga, dua raksasa penunggu hutan, dan seekor naga penjaga lautan. Pada akhirnya Bima mampu mencapai keinginannya dengan mendapatkan anugerah tirta pawitra dari Dewa Ruci. Peristiwa pertemuan antara Bima dengan Dewa Ruci sangat menarik karena terkait dengan gambaran pengalaman religius dalam usaha menyatu dengan Illahi. Proses persatuan antara manusia dan khalik dalam pandangan Jawa dinyatakan sebagai manunggaling kawula-gusti.

Usaha Bima untuk menuju pada kesempurnaan hidup dilalui dengan berbagai tingkatan. Tingkatan demikian dinamakan laku atau mistikisme. Dalam lakon Dewa Ruci tahap-tahap penting yang dilalui Bima adalah: berguru kepada pandita Durna; patuh dan teguh dalam melaksanakan perintah guru; menghancur-kan hutan Tikbrasara serta mampu menyingkirkan penghalangnya; meruwat Dewa Bayu sebagai amal kebaikan; kembali berguru pada Durna atau tidak putus asa untuk bertanya; menyingkirkan dan meninggalkan saudaranya yang merintangi tujuan; terjun ke samodra Minangkalbu; membunuh Naga Nemburnawa atau nafsu duniawi; mati sajroning urip dan menyerah dengan iklas pada kuasa Tuhan; bertemu Dewa Ruci untuk menerima cahaya tuntunannya; manunggal dan berdialog untuk menerima air hidup (Mulyono, 1979:61; Tanaya, 1979:1-24; Mangkuna-goro, 1933:23-24).

Untuk memahami perjalanan Bima hingga menemukan air kehidupan dapat ditelusuri melalui struktur dramatik lakon. Dalam hal ini, alur lakon memberikan gambaran yang jelas mengenai usaha Bima menjumpai Dewa Ruci. Pada pertunjukan wayang sinema lakon Dewa Ruci ini, memiliki alur yang lebih padat dengan penekanan pada adeganadegan penting. Adapun alur lakon Dewa Ruci sebagai berikut.

1. Bima dilahirkan dalam wujud plasenta (bungkus). Peristiwa kelahiran Bima menggegerkan dunia, sehingga Batara Bayu memerintah-kan kepada Gajahsena untuk memecahkan bungkus. Pada akhirnya bungkus dapat pecah dan Gajahsena merasuk ke dalam diri Bima.

2. Bima digambarkan sebagai manusia perkasa. Inilah Bima, manusia perkasa, putra Pandu dan Kunti, memiliki banyak julukan, Bratasena, Werkudara, Kusumadilaga, Balawa, Bayusiwi, Harya Sena, manusia sakti mandraguna, suka menolong kepada sesama.

3. Bima merenungkan berbagai peristiwa sebagai refleksi diri.

Bima bercita-cita menjadi insan kamil, sebagai ksatria sekaligus berjiwa brahmana, berguna bagi negara, mampu menjadi taladan hidup, menjadi sumber petunjuk akan keilahian, ingin menyatu dengan mikro dan makro kosmos.

4. Bima bertekad mencari guru yang memiliki kemampuan luar biasa. 
Bima ingin mencari manusia yang penuh ilmu pengetahuan dan ilmu kanoragan, seorang guru sejati yang memberi petunjuk kebaikan dan kemaslahatan dunia, Bima mengungkap orang sakti di dunia, yakni Resi Durna.

5. Bima memutuskan berguru kepada Pendeta Durna untuk ilmu kesempurnaan hidup.

Bima memutuskan untuk berguru pada Resi Durna, ia ingin mencari air kehidupan menuju insan kamil. Bima melakukan perjalanan menuju Sokalima, ia seorang diri tanpa ditemani siapapun, hanya angin besar yang menyertai kepergiannya, perjalanan Bima mampu menggetarkan dunia, membuat takut masyarakat pedesaan yang dilaluinya, akhirnya Bima sampai di Padepokan Sokalima dengan semangat membara.

6. Bima menjumpai Durna di Negara Astina, dan mengutarakan niatnya untuk mencari kesempurnaan hidup.

Bima bersimpuh dihadapan Resi Durna, ia mengutarakan niatnya untuk berguru kepada Resi Durna, ia menginginkan kesempurnaan hidup demi menjaga keselarasan dunianya, Resi Durna menyambut hangat keinginan muridnya.

7. Resi Durna memberikan petunjuk tentang air kehidupan (tirta pawitra) yang harus ditemukan Bima.

Resi Durna memberikan petunjuk kepada Bima mengenai jalan menuju kesempurnaan hidup, ia diminta untuk mencari tirta pawitra (air kehidupan), air yang memberi daya hidup dan daya suci kepada insan kamil.

8. Pada tahap pertama Bima mendapat petunjuk untuk pergi ke hutan mencari kayu gung susuhing angin.

Resi Durna memberikan petunjuk pertama bahwa persyaratan memperoleh air kehidupan dimulai dengan mencari kayu gung susuhing angin, kayu ini berada di pusat Gunung Reksamuka, Bima berpami-tan menuju hutan.

9. Bima memasuki hutan Candramuka (Reksamuka). Perjalanan Bima menuju ke hutan dengan niat untuk menemukan kayu gung susuhing angin, ia mengandalkan kekuatan spiritualnya dengan ajian sepi angin, bagaikan gerakan angin taufan perjalanan Bima sampai di hutan, ia mulai mencari kayu gung susuhing angin dengan merobohkan pepohonan, memindahkan bebatuan, memasuki goa, menuruni lem-bah curam, bahaya alam tak dihiraukannya. Kekacauan di hutan membangkitkan kemarahan sang penunggu yaitu
Rukmuka dan Rukmakala, segera mereka menghampiri Bima.

10. Bima berseteru dengan Rukmuka-Rukmakala.

Bima dihadang dua raksasa, Rukmuka dan

Rukmakala, keduanya marah atas perilaku Bima merusak hutan, membuat hewan hutan ketakutan. Bima hanya menjalankan perintah guru untuk menemukan kayu gung susuhing angin, terjadi perseteruan dengan dua raksasa, akhirnya Bima dikeroyok dua raksasa hingga terjadi peperangan sengit.

11. Bima mampu membinasakan dua raksasa jelmaan Bayu yang memberikan anugerah kepada Bima berupa gelung minangkara.

Bima mampu menguasai lawan, bahkan membunuh kedua raksasa. Tiba-tiba kedatangan Dewa Bayu menghampiri Bima, Bima mendapat anugerah dewata karena telah menolong kedua dewa yang tengah menjalani hukuman, Dewa Bayu memberikan anugerah berupa gelung minangkara, hingga tampilan Bima berubah menggunakan gelung. Dewa Bayu memberikan saran agar Bima kembali menemui Durna, karena apa yang dicari tidak ada di hutan.

12. Bima keluar hutan untuk menemui Durna di Sokalima.

Setelah mendapat petunjuk dari dewata, Bima keluar hutan memilih jalan pintas dengan menuruni lembah curam dan menyeberangi anak sungai, perjalanan Bima semakin dipercepat demi menghadap pada gurunya di Sokalima, Bima telah sampai di padepokan dan segera mencari Durna.

13. Bima telah menghadap Durna, dan diberi petunjuk kedua, untuk mencari tirta pawitra di samodera.

Dihadapan sang guru, Bima menyampaikan peristiwa yang dialaminya, ia tak mendapatkan kayu gung susuhing angin, namun mendapat anugerah dari Dewa Bayu dan Dewa Indra. Durna memberikan petunjuk kedua bahwa air suci ada di samodera selatan. Bima diminta untuk melakukan perjalanan panjang ke samodera demi mendapatkan tujuannya. Bima berpamitan untuk melaksanakan petunjuk gurunya, dengan gejolak jiwa yang besar karena harus berhasil mewujudkan impiannya, ia akan pulang dahulu minta restu orang tua dan saudaranya.

14. Bima menjadi bahan pembicaraan saudaranya di Amarta.

Bima menjadi bahan pembicaraan orang tua dan saudaranya, bahkan Puntadewa menghadirkan Kresna untuk membantu menghentikan niatan 
Bima, Kresna hadir di Amarta, ia menyampaikan pesan bahwa Bima akan mampu mengatasi permasa-lahannya sendiri, Kresna menasihati agar Pandawa bersabar untuk menunggu kepulangan Bima.

15. Bima menuruti petunjuk Durna, namun dia kembali ke Amarta dulu untuk minta restu ibu dan saudaranya. Bima tidak diperbolehkan ke samodera oleh keluarga besarnya, namun tetap nekad menuruti nalurinya.

Bima hadir di Amarta menggegerkan suasana persidangan, orang tua dan saudaranya merasa lega atas kepulangan Bima, Bima menyampaikan niatannya untuk pergi ke samodera, ia minta pamit dan doa restu dari orang tua dan saudaranya, niatan Bima dicegah orang tua dan saudaranya, namun Bima tetap pada keinginannya untuk menemukan air kehidupan di samodera.

16. Bima melakukan perjalanan ke samodera untuk mencari air kehidupan.

Bima melesat dari kerajaan Amarta, ia memulai lagi perjalanan panjang menuju samodera, perjalanan bagaikan angin, telah sampai di hutan belantara, Bima mencari jalan terdekat untuk sampai di samodera, ia menaiki gunung, menuruni lembah, masuk keluar hutan belantara, dan menyusuri bibir sungai yang panjang.

17. Bima bertemu dengan Anoman, Maham-bira, Setubanda, dan Jajakwreka hingga terjadi perkelahian, namun Bima tetap mampu meloloskan diri.

Di tengah perjalanan, Bima dihadang kadang bayu, mereka terlibat pembicaraan, Para kadang bayu menyarankan agar Bima mengurungkan niatnya menuju samodera karena hanya diperdaya Durna dan Kurawa, Bima teguh dalam pendirian, dan tetap melanjutkan niatannya untuk menemukan air kehidupan. Terjadi dorong mendorong, namun kadang bayu kalah oleh kekuatan Bima, segera Bima melesat jauh meninggalkan kadang bayu.

18. Bima sampai di tepi samodera, memandangi keganasan air samodera.

Perjalanan Bima sampai di tepian samodera, ia memandangi samodera nan luas, terlihat jelas keganasan ombak bergulung-gulung menerjang batu karang, Bima merasa ragu untuk memasuki samodera.

19. Bima mendapatkan penguatan dari burung perkutut, gemak, dan platuk bawang.

Keraguan hati Bima diberi penguatan oleh pembicaraan tiga burung yang ingin mencari kehidupan yang lebih baik dengan cara bertekad bulat dalam hati.

20. Bima dengan tekad membara memasuki samodera hingga mendapat gangguan dari Naga Nemburnawa.

Bima menceburkan diri ke samodera disambut gulungan ombak, Bima terlarut dalam balutan ombak besar, ia telah berada di tengah samodera, badannya terombang-ambing derasnya air laut, ia menyelam ke dalam hingga mencapai dasar samodera, kelebat Naga Nembur-nawa mendekat mencium aroma tubuh Bima, Bima menghindar dari terjangan Naga, semakin menghindar maka semakin ganas pula Naga ingin memangsa Bima.

21. Bima lemas tiada daya akibat lilitan dan gigitan Nemburnawa, namun Bima menemukan kesadarannya kembali dan berhasil membunuh Nemburnawa.

Bima terlena, Naga Nemburnawa menyibakkan ekornya mengenai tubuh Bima, Bima terpental jauh di dasar samodera, Naga semakin mengganas, Naga melilit sekujur tubuh Bima, Bima lemas tiada daya, ia terlena dalam cengkeraman Naga Nemburnawa. Sang Naga menggigit tubuh Bima, dalam kesadaran akhir Bima memegang mulut naga, dengan Kuku Pancanaka, Bima merobek leher naga, Nemburnawa melepaskan lilitannya, Bima mengejar dan menyobek mulut naga hingga tewas. Darah membasahi lautan hingga menghilangkan kesadaran Bima, ia seolah terlempar ke dunia yang tak dikenalnya.

22. Bima tertelan air samodera dan telah bersimpuh di hadapan Dewa Ruci.

Bima terbawa aliran dalam air samodera, ia telah berada di hadapan Dewa Ruci, Bima tersadar namun terheran menyaksi-kan adanya sosok kecil dirinya di hadapannya, sosok Dewa Ruci telah membukakan tabir perjalanan Bima, Bima segera bersimpuh dan menyembah kepada Dewa Ruci, Bima menyatukan hati dan pikirannya dengan Dewa Ruci.

23. Bima mendapatkan tirta pawitra dari Dewa Ruci. Dalam keheningan Bima mendapatkan pencerahan batin dari Dewa Ruci, Bima merasakan mendapatkan kenikmatan luar biasa karena berada di sisi Dewa Ruci, Bima mendapatkan wejangan Pancamaya, ia mendapat pula wejangan Jatitunggal saliring warna, berikutnya wejangan Pramana, wejangan Reh pepingitaning jagat, dan juga mendapat wejangan Pungkasan. 
24. Bima diminta kembali lagi ke negara Amarta.

Bima telah menerima berbagai ilmu kesempurnaan hidup dari Dewa Ruci, Bima telah menerima air kehidupan, Bima merasakan kenikmatan tiada tara dan memilih untuk berada di alam walikan, Dewa Ruci menyarankan agar Bima segera kembali ke dunia nyata untuk mengabdikan diri, untuk mengamalkan ilmu kesempurnaan hidup yang telah diberikan, Bima berpamitan dengan Dewa Ruci, Bima melesat keluar dari dasar samodera, Bima telah berada di tepian samodera, ia meninggalkan samodera.

25. Bima menuju Padepokan Sokalima

Bima tidak pulang ke Amarta, ia menuju ke Padepokan Sokalima menemui gurunya Durna untuk menyampaikan rasa terima kasih yang mendalam atas petunjuk sang guru. Bima berkumpul kembali dengan saudara dan ibunya.

\section{KESIMPULAN}

Pertunjukan wayang sinema merupakan salah satu corak estetika pertunjukan wayang dari perpaduan antara wayang klasik dengan teknologi modern. Wayang sinema mengangkat lakon Dewa Ruci yang syarat dengan nilai pengajaran budi pekerti masyarakat Indonesia. Wayang sinema menjadi model pengembangan wayang Indonesia dalam dinamika industri 4.0. Ini artinya wayang telah melebur dengan perkembangan zaman sehingga mampu hidup dan bertahan serta dapat menjembatani minat generasi muda terhadap wayang.

Pertunjukan wayang sinema didasarkan pada konsep utama, yakni konsep pertunjukan, konsep sabetan wayang, konsep narasi, dan konsep musik. Konsep pertunjukan adalah wayang dalam bentuk layar lebar atau film sehingga menarik bagi masyarakat secara umum. Konsep sabetan menerapkan gerakan wayang yang representatif mewakili maksud dan tujuan para tokoh dalam rangkaian alur lakon. Konsep narasi memberi pemahaman mengenai penggunaan narasi dan dialog wayang melalui runing teks ataupun syair tembang. Konsep musik memberikan pemahaman tentang penggunaan gending, sulukan, sindhenan, gerongan, dan tembang untuk menguatkan suasana adegan dan batin tokoh wayang dalam alur lakon.

Konsep dasar pertunjukan wayang sinema diimplemntasikan menjadi garap pertunjukan wayang sinema lakon Dewa Ruci. Garap pertunjukan wayang sinema membutuhkan penggarap, yakni sutradara, penulias naskah, dalang, pengisi vokal; peralatan garap, yaitu gamelan, wayang, lampu, handycam dan lain-lain; sarana garap terdiri atas vokal-instrumental, sabetan, antawecana, gending, wayang, dan sebagainya. Hasil garap pertunjukan wayang sinema lakon Dewa Ruci berupa film layar lebar mengenai lakon Dewa Ruci.

\section{DAFTAR PUSTAKA}

Fosdhal, Frank. 2004. "Lakon Wayang Wahyu Binuka Wahyu Jati Manunggal" Kertas Penciptaan Seni pada Program Pascasarjana ISI Surakarta.

Kuwato. 1990. "Tinjauan Pakeliran Padat Palguna Palgunadi Karya Bambang Murtiyoso DS" Laporan Penelitian STSI Surakarta.

2001. "Pertunjukan Wayang Kulit di Jawa Tengah Suatu Alternatif Pembaruan: Sebuah Studi Kasus". Tesis UGM Yogyakarta.

Mangkunegoro VII, KGPAA. 1933. "On the Wayang Kulit (Puwa) and Its Symbolic and Mystical Elements". Terjemahan Claire Holt Original text published in Jawa. Vol. XIII,

Mulyono, Sri. 1975. Wayang Asal-usul Filsafat dan Masa Depannya. Jakarta: Alda.

Murtiyoso, Bambang, Sumanto, Suyanto, Kuwato. 2007. Teori Pedalangan: Bunga Rampai Elemen-elemen Dasar Pakeliran. Surakarta: ISI Surakarta Press dan CV Saka Production.

Musbikin, Imam. 2010. Serat Dewa Ruci (Misteri Air Kehidupan). Jogjakarta: Diva Press.

Rianto, Jaka, Sunardi, Titin Masturoh. 2010. Buku Panduan Praktik Pakeliran Golek Padat. Surakarta: ISI Press Surakarta.

Santoso, Trisno. 2016. "Wayang Boneka Wong Agung Jayengrana. Disertasi Pascasarjana ISI Surakarta.

Satoto, Soediro. 1989. Pengkajian Drama I. Surakarta: Sebelas Maret University Press. 
Subono, B. 2002. "Wayang Lingga-Yoni Lakon Pengakuan Seorang Pradana". Kertas Penciptaan Seni pada Program Pascasarjana ISI Surakarta.

Sunardi. 2013. Nuksma dan Mungguh: Konsep Dasar Estetika Pertunjukan Wayang. Surakarta: ISI Press.

2004. "Pakeliran Sandosa dalam Perspektif Pembaharuan Pertunjukan Wayang. Tesis STSI Surakarta.

Sunardi, Bambang Suwarno, Bagong Pujiono. 2014. Revitalisasi dan Inovasi Wayang Gedog. Surakarta: ISI Press.

Sunardi, Kuwato, Sudarsono. 2017. Estetika Pertunjukan Wayang Perjuangan. Surakarta: ISI Press.
Sunardi, Kuwato, Zulkarnaen Mistortoify. 2009. "Wayang Transparan: Wayang Eksperimen Berbahasa Indonesia sebagai Sarana Transmisi Pendidikan Budi Pekerti bagi Siswa SLTA di Surakarta" Laporan Penelitian Dirjen Dikti Kementerian Pendidikan dan Kebuda-yaan.

Sunardi, Sugeng Nugroho, Kuwato. 2016. Wayang Babad Nusantara Media Pengajaran Nilai Kebangsaan. Surakarta: ISI Press.

Suryanto, Dwi. 2007. "Wayang Terawang Lakon Anoman Sang Maha Satya". Kertas Penciptaan Seni pada Program Studi Seni Pedalangan.

Tanaya, R. 1962. Serat Dewa Ruci Kidung. Surakarta: Toko Buku Pelajar

Tanaya, R. 1979. Bima Suci. Jakarta: Balai Pustaka. 